\title{
Rethinking The Theology Text Of Islam In Nusantara: Serat Cebolek, Meurukon, Rabbani Wahid Poem, And Peurateb Aneuk
}

\author{
Zulfikar Ali Buto ${ }^{1}$, Muhajir ${ }^{2}$, Mohd. Harun Ar Razi ${ }^{3}$, Muhammad Iqbal $^{4}$ \\ IAIN Lhokseumawe ${ }^{1}$ \\ UIN Sunan Kalijaga Yogyakarta ${ }^{2}$ \\ Universitas Syiah Kuala ${ }^{3}$ \\ Sultan Idris Educational University ${ }^{4}$ \\ IAIN Lhokseumawe ${ }^{5}$

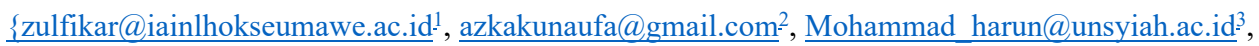 \\ razi.aceh@gmail.com ${ }^{4}$, iqbal@iainlhokseumawe.ac.id $\underline{5}$ \}
}

\begin{abstract}
The era of digital technology 4.0 and literacy today has changed how people think and behave on anything, including on theological texts where people now are having fewer interests. The use of these texts as a reference and a learning media has been now declining. Moreover, people have no attention to theological texts for they are now prone to superficial readings on spiritual values. This article examines the use of Islamic theological texts by discussing and bringing back some of the texts through literacy. The texts include SeratCebolek, Meurukon, Rabbani Wahid's poems, and PeuratebAneuk. Using an interdisciplinary approach, this article is an attempt to shed light on the contents and meanings in the texts in order to change the paradigm of society, which is logic, systematic, and based on a definite creed. This article argued that these sacred texts contain theological elements full of meanings and substantial values capable of fortifying the readers against things contrary to religious and state laws. In addition, the nuances, the atmosphere, and the conflicts presented in the texts enable to calm down the readers because the conveyed messages are driving the soul to the Divine Rabbi. Therefore, reviving the "spirits" of the texts in this digital era through digitization and literacy can actualize theology that once ever existed.
\end{abstract}

Keywords: Serat Cebolek, Meurukon, Rabbani Wahid poems, PeuratebAneuk

\section{Introduction}

The era of digital technology 4.0 and literacy today has changed the way people think about something. The way of life, thinking, and behavior has also changed, including the community's perspective on theological texts. The use of these texts for a reference and learning media is no longer given priority in society. In addition, attention to the theological texts has also changed for the community prefers to dig up spiritual values through superficial readings that contribute to the birth of apathetic, radical, and extreme points of view. This article will discuss the use of Islamic theological texts by reviewing and actualizing the theological texts through literacy. The texts being discussed in this article include Serat Cebolek, Meurukon, Rabbani Wahid poems, and PeuratebAneuk. 
Serat Cebolek. One of the Javanese literary works that explain the story of Sheikh Mutamakkin is Serat Cebolek [1]. This book, which is taking the form of poems, was written by Raden Ngabehi Yasadipura I (1729-1803). Some researchers have not yet agreed on who wrote this sacred text. For example, Ricklefs is a historian who doubts about the attribution to Raden Ngabehi Yasadipura I. However, he said that the Javanese community, especially those who are living in the palace and priyayi environment, accepted that Serat Cebolek was written by R. Ng. Yasadipura I [2]. This literary work is phenomenal because it records the events in which Sheikh Mutamakkin is developing his rebellious theosophy.

In Serat Cebolek, Sheikh Mutamakkin is described as a mystic (Sufi) with a low personality. Furthermore, he is considered a figure whose knowledge is shallow and his authority and ethics are low (Bizawie, 2014: 130). Some researchers said that this text is discrediting Sheikh Mutamakkin. This brings us to the question of why Serat Cebolek portrays this figure with a lack of respect.

Based on the social-historical context, there are at least two reasons why the description of Sheikh Mutamakkin was considered as a form of discrediting. The first is that Serat Cebolek written by R. Ng. Yasadipura I as a poet of Keraton Surakarta is not the only text that tells about Sheikh Mutamakkin. There are other texts telling the story of this Sufi cleric, one of which is the Kajen Text. This manuscript is a collection of oral histories about Sheikh Mutamakkin. The stories continue to spread in this community whose ancestors have direct life experience with Sheikh Mutamakkin. Kajen area located in Pati Regency has become one of the centers of Sheikh Mutamakkin's religious activities during his lifetime. The Kajen Text becomes a comparison for the Serat Cebolek in regard to the story of Sheikh Mutamakkin. The description of the Sufi in Kajen Text turns to be far different from what presented in Serat Cebolek [3].

Meurukon. Among the Acehnese, there is an Islamic art well known as meurukon. The main media for meurukon is oral poetry in the form of religious songs. Each meurukon group occupies a particular hall that has been prepared for eight to ten people. On top of the opposing hall, the meurukon group asked and answered each other. The audience stood or sat cross-legged around the meurukon arena in a solemn manner [4], [5].

The creator of meurukon believes that learning with oral poetry media can create a pleasant learning environment. This is in line with Joyce and Weil's [6] view that one of the goals of learning is to create an environment to facilitate learning. Besides, meurukon is designed to become an interactive-dialogic learning media. The term 'dialogical' can refer to behaviors that respect each other's different ideas [7]. Interactive-dialogic learning is a teaching-learning technique to motivate learners to ask and answer questions (question-answer) while learning. This model of learning is believed to increase the intelligence or thinking skills of learners because they are invited to think deeply when engaging in an interactive dialogue [8]-[11].

One of the substantive parts of meurukon is theology, a term that comes from a Greek language, theology, from the word Theos (God) and logos (discourse or science) [12]. In other words, theology is the science of divinity, which is related to the substance of God, the nature of God, the words of God, and the actions of God from all its aspects. It seems that scholars are well aware that theology is the most fundamental problem in religious life. Theological problems in Islam are usually associated with the terms aqidah, kalam, faith, and monotheism. These four terms lead to the concept of God, which in principle refers to a systematic effort to make a Muslim bound to all sides of the existence of God in their lives.

Rabbani Wahid Poetry. Rabbani Wahid Poetry is not different from general poetry. It is also often referred to as meugrob Poetry. The word meugrob means jumping motion carried 
out by a group of teenagers or adults holding each other's hands while reading "Allahu" and "la ilahaillallah" repeatedly until reaching a "peak" condition and situation.

The poetry concretely is an old poem being developed in a society in the form of prose consisted of four lines each of which contains eight to ten syllables. Poetry is not divided into sampiran and content, but all of them are contents and are generally sequential because they are used to paint stories. In Aceh, poetry is also defined as the definition of poetry in general, and Rabbani Wahid poetry is the same as Meugrob's Poem, but it is called by Meugrob's Poem only when the poem is being sung by jumping.

PeuratébAneuk. Peuratébaneuk is the sleep activity of children being accompanied by peuratébaneuk/dodaidi poems so that the child is swayed in a swing because he or she enjoys poetry sung by a mother with a melodious and melodious rhythm. As a religious region, the Acehnese people use the text peuratépaneuk as a media literacy in embodying Islamic theology to children. This media is used by mothers to pray for their children to have high skills [13].

This sacred text was inherited from generation to generation among the Acehnese people. This is because the text contains the values of Islamic education and theology that need to be passed on to children from an early age. The parents hope that one day their children will grow and develop according to religious teachings and strong monotheism or faith so that the characters that underlie their children's lives will always be useful for families, communities, nations, and religions.

\section{Method}

This research uses a qualitative approach to content analysis. The data sources are documents and informants. The documents referred to include the sacred texts of Serat Cebolek, Meurukon, Rabbani Wahid, and Peurateb Aneuk. The data were collected through the techniques of document reviews and open interviews. The data analysis follows the steps (a) reading the contents of these texts in earnest (verstehen and erlebnis), (b) grouping data into theological substance or contents, (c) analyzing the data comprehensively according to the focus of the study, (d) summarizing the results of research, and (e) verifying the results of research with experts and colleagues.

\section{Result and Discussion}

In Meurukon, many texts were found on theological issues, both directly related to the concept of God and those related to the practice of faith and creed. The following data shows the questions and answers regarding the issue of religion and attributes possessed by God [14].

\begin{tabular}{|l|l|}
\hline Su-eue & Question \\
\hline Meutoh agama sebenarnya ulon sudi & Which religion is I ask about \\
Peugah beumeuri abeh mandum hai & Explain in detail, O Sheikhuna \\
syaikhuna & All of us must know one God \\
Mandum geutanyoe sidroe Tuhan & What are the qualities, please say \\
beutaturi & Sheikhuna \\
Padum boh sipheuet neuci seubut hai & \\
\hline
\end{tabular}




\begin{tabular}{|l|l|}
\hline syaikhuna & \\
\hline Jaweueb & Answer \\
\hline Awaluddin makrifatullah & Awaluddin makrifatullah \\
Awai agama dilee beutaturi Allah & The beginning of religion is to know \\
Taturi Allah na dua ploh sipheuet & God \\
Jinoe lonkheun deungo bandum hai & Get to know God with 20 qualities \\
syaikhuna... & I'll explain, please listen, O \\
& Sheikhuna... \\
\hline
\end{tabular}

The interactive discussion as illustrated in meurukon above explains that someone is said to have been religious (Islam) if he already knows God. That is, before knowing God, he was not a Muslim. Then it is made explicit that the essential way to know God is to know all the twenty of divine attributes. In other words, if someone does not know the 20 attributes of God, that person is not yet religious, because he or she does not know God. Consequently, someone who only knows some of the twenty attributes is not yet perfect in his Islam. Therefore, the true Muslims are those who know and believe in the twenty attributes of Allah. In this context, it appears that Islam and faith are two inseparable things.

On the other hand, Rabbani Wahid poetry contains Islamic values regarding the sociocultural aspects of Aceh in the form of art. This can be seen from the informational functions of poetry that are all Islamic. This poem functions to connect hospitality as one of the poems in Rabbani Wahid, i.e. Saleum. Also, this poem serves as a medium for the preservation of customs and as entertainment in the context of celebrating Islamic holidays. Rabbani Wahid poetry also becomes an educative media within a socio-cultural frame related to worship, the oneness of God, and da'wah.

The sacred text of Peurateb is full of Islamic theology, as it is indicated by the expression of tayyibah sentence, being instilled to the children in the Acehnese society. The sentence was conveyed through the peuratébaneuk poem. This expression of tayyibah is used at the beginning of poetry.

\begin{tabular}{|c|c|}
\hline Text of Peurateb Aneuk & Meaning \\
\hline Lã ilaãha illallah & no God b \\
\hline $\begin{array}{l}\text { Kalimah tayyibah pangkai } \\
\text { tamaté }\end{array}$ & $\begin{array}{l}\text { The sentence tayyibah is prepared to face } \\
\text { death, }\end{array}$ \\
\hline $\begin{array}{l}\text { Soe tém baca kalimah } \\
\text { tayyibah }\end{array}$ & $\begin{array}{l}\text { Whoever has the chance to read the tayyibah } \\
\text { sentence }\end{array}$ \\
\hline $\begin{array}{l}\text { Tubôh nyang sah azeub han } \\
\text { lé. }\end{array}$ & $\begin{array}{l}\text { Will not suffer punishment when life is } \\
\text { separated from a body. }\end{array}$ \\
\hline
\end{tabular}

Lãilaãhaillallah is a monotheistic sentence for the Acehnese who has a high religious level. It is mandatory to introduce the sentence to their children earlier in the crib. Furthermore, the parents in Aceh also teach their children to read the "kalimah tayyibah pangkai tamate". This tayyibah sentence is believed to be the last word that will be uttered when someone is about to die. Therefore, before leaving this world it is obligatory to practice the contents of the Lãilaãhaillallah sentence. Because they have pledged the sentence, They 
are bound to follow all His commands and leave all His prohibitions. The parents, through the peuratébaneuk poem, are instilling the sentence tayyibah as a modal in leaving this world and returning to Allah. When lives are separated from the body, the tayyibah sentence is the last word to say.

In the next line in the poem of peuratébaneuk above, the parents also conveyed to the child, "sötém baca kalimah tayyibah, tubôh nyang sah azeub hanlé." The peuratéb poem means that is when someone could utter the sentence of tayyibah at the end of his life, he or she will not receive punishment from Allah in the tomb. This is in line with the words of the Prophet Muhammad, "Whoever ends his words before dying with lãilaãhaillallah, he will go to heaven."

The poem of Peuratébaneuk contains the value of monotheism education. The parents in Aceh teach their children to know God Almighty from an early age, with the hope that in the future their children will grow up with a strong faith. The parents also teach the children the tayyibah sentence, i.e. lãilãhaillallah as provision when the last breath blows away from this world. The parents in Aceh convey the message of monotheism to children, as seen from the following poem of Peuratébaneuk:

\begin{tabular}{ll}
\hline Text of Peurateb Aneuk & Meaning \\
\hline Lã ilãha illallah & There is no God but Allah \\
Kalimah tayyibah keu ubat haté & The tayyibah sentences as medicine \\
Taduek tadöng beurangkapat & Wherever you are \\
Allah taingat dalam haté. & Always remember God in the heart \\
\hline
\end{tabular}

The above Peuratébaneuk poem also contains the message of monotheism for the children. The poem introduces the sentence lãilãhaillallah with two other things that parents want to instill into their children, i.e. monotheism as a medicine for the heart and that the children always remember Allah. The word lãIlãhaillallah is a monotheistic sentence, which means, "There is no god but Allah." Through the peuratébaneuk poem, the parents educate their children to acknowledge the oneness of Allah as a disclaimer of the other gods and assert that Allah is the only god to worship. Indeed, Allah is a substance that does not need anyone at all. Allah is Almighty, and there is no god but Him. The Prophet said, "The main remembrance is lãilãhaillallah and the special prayer is Alhamdulillah.

Based on those paragraphs above we can do some analysis. The presence of Serat Cebolek written by R. Ng. Yasadipura explained the figure of Sheikh Mutamakkin who was in conflict with the Mataram Kertosuro coastal scholars led by KetibAnom Kudus and successfully reconciled by Susuhunan Pakubuwono II. Sheikh Ahmad al-Mutamakkin was a Sufis, i.e. a cultural cleric who had a significant role in spreading the message of Islam in the north coast (pantura) Island of Java in the 18th century AD. The regions where he preached stretched from the Tuban, Rembang, and then ended up in the village of Kajen, Margoyoso, Pati.

The teachings of Sheikh Mutamakkin's theosophy include harmonization of the Shari'a, Muhammad Khakiki (The Nature of Muhammadiyah) and divine freedom (al-Hurriyah). The media that Sheikh Mutamakkin used in teaching often made use of local cultural texts, such as the story of Bimasuci and Dewaruci. The three teachings above are claimed to be heretical by the majority of scholars who are the bearers of royal authority on the coastal area. Sheikh Mutamakkin has also labeled a rebel because his teachings challenged the vision of the kingSufi palace. The contextualization of Sheikh Mutamakkin's theosophical teachings leads to an egalitarian social life. Sufism in the political context is not as a means of legitimating power 
but as a source of energy to scale strategic politics, cultural politics and humanitarian politics. Sufism does not only belong to the elite, but it is a space that has the right to be accessed by anyone for a long process towards mukasyafah and closeness to God.

The theological elements being discussed in meurukon are (a) the concept of Islamic religion and the attributes of God; (b) the concept of faith; (c) the concept of Islam; (d) the classification of God's twenty attributes; (e) faith in angels; (f) signs of doomsday; (g) obligatory prayers or especially the prayer posts; and (h) Apostles' commands, such as the dowry on marriage matters.

Rabbani Wahid poetry takes the form of physical and mental structures. The physical structure includes the use of diction, judgment, concrete words, figurative language, and version. The inner structure includes themes, feelings, tone and atmosphere, and the message. In addition, the function of Rabbani Wahid is informational, expressive, aesthetic, and educative. Rabbani Wahid is essential to be revived because it implies the one God of Rabbi. This can illustrate the identity of this poem because it contains praise to Allah and advice and stories that all aim to get closer to Allah.

The sacred text of peuratéb also contains a deepening of theology. Strictly speaking, this text introduces the phrase monotheism including AllahuAllah Allahurabbôn, Allah qadirôn almighty. It can be interpreted that in putting their children to sleep the Acehnese parents are reciting peuratébaneuk poems as a medium of learning and teaching materials to pass on monotheistic messages to their children. For them, monotheism is a necessary foundation that must be instilled into children from an early age. In Aceh, mothers are educating their children about monotheism as earlier as possible.

The four types of texts could be revived by digitizing them in the form of applications. In addition, the actualization of the texts through literacy can be done through reintroducing the holy texts in institutions and occasions, such as pesantren, extracurricular activities in religious school institutions, routine activities at celebrations of religious holidays, such as Nuzulul Quran and the Prophet's Birthday, intergroup, inter-district, and district/city competitions for children, youth, and adults, broadcasts on television media for introduction and habituation, and rice harvest parties. Moreover, the sacred texts could be also a teaching material or course in literary and art-based universities.

\section{Conclusion}

It is no doubt that the sacred texts of the archipelago of Islam contain materials and meanings loaded with theology. The sacred texts include Serat Cebolek, Meurukon, Rabbani Wahid, and PeuratebAneuk. All these texts will challenge the people's ways of thinking that are logical, systematic, and based on a definite creed. The reason is that these sacred texts contain a theology that is full of meaning and substantial values; the texts are also active in fortifying the readers about things that are contrary to religious and state laws. In addition, the nuances and atmosphere, as well as the conflicts developed in the texts, can calm the readers because the messages they want to convey are taking the soul to Divine Rabbi. Thus, reviving the "spirits" of the texts in this digital era through literacy will help to actualize a theology that once existed through digitization and literacy. 


\section{References}

[1] Z. B. Milal, Syekh Mutamakkin: Perlawanan Kultural Agama Rakyat. Tanggerang: Pustaka Compass, 2014.

[2] M. . Ricklefs, "The Yasadipura Problem,” BKI, vol. 153, no. 2, p. 276, 1997.

[3] M. S. W. dan S. Bagus, "Pemikiran Neo-Sufisme Syaikh Ahmad Mutamakkkin," Theologia, vol. 29, no. 2, p. 28, 2018.

[4] M. Harun, Pengantar Sastra Aceh. Bandung: Citapustaka Media Perintis, 2012.

[5] M. Harun, Memahami Orang Aceh. Bandung: Citapustaka Media Perintis, 2009.

[6] B. dan W. M. Joyce, Models of Teaching Englewood Cliffs, 2nd ed. New Jersey: Prentice-Hall, Inc, 1980.

[7] M. Bakhtin, Speech Genres and Other Late Essays. Austin: University of Texas Press, 1986.

[8] R. . Alexander, Towards Dialogic Teaching, 3rd ed. New York: Dialogos, 2006.

[9] S. Lyle, "Dialogic Teaching: Discussing Theoretical Contex and Reviewing Evidence From Classroom Practice," Lang. Educ., vol. 22, no. 3, pp. 202-240, 2008.

[10] P. Mortimer, E. F., \& Scott, Meaning Making in Science Classrooms. Milton Keynes: Open University Press, 2003.

[11] D. Skidmore, "Pedagogy and Dialogue," Cambridge J. Educ., vol. 36, no. 4, pp. 503514, 2006.

[12] L. Bagus, Kamus Filsafat. Jakarta: Gramedia Pustaka Utama, 2002.

[13] S. Hurgronje, Aceh Di Mata Kolonial. terj. Ng. Singa Rimbun. Jakarta: Yayasan Soko Guru, 1985.

[14] N. Huda, Profil Group Meurukon Gampong Pulo Bungong Kecamatan Batee Kabupaten Pidie. Pidie: Group Meurukon Nuril Huda, 2018. 